\title{
Spontaneous Arthritis in Nude Rats of Rowett Hooded Strain
}

\author{
Kenji MACHII, Shoji YAMAZAKI, Hiroshi IWAI, Reiko SANO \\ and Katsumoto UEDA \\ Department of Veterianry Public Health, Institute of Public Health, 4-6-1, \\ Shiroganedai, Minato-ku, Tokyo 108, Japan
}

(Received 25 May 1984 / Aceepted 22 August 1984)

\begin{abstract}
Spontaneous arthritis was found in 19 of 55 Rowett hooded strain rats with rnu gene. Most cases were in the male rnu/rnu (15/19) but a few occurred in the male $\mathrm{rnu} /+(3 / 10)$ and female $\mathrm{rnu} / \mathrm{rnu}(1 / 8)$. The lesions were first noted as reddened swelling due to exudative inflammation of periarticular soft tissues including synovial membranes in the tarsal and/or carpal joints. Most of the affected animals cured leaving slight induration but in a few male $\mathrm{rnu} / \mathrm{rnu}$ ankylosis with pannus formation and exostosis developed. No sign of mycoplasmal or bacterial infection was noticed in the colony.
\end{abstract}

Naturally occurring degenerative or inflammatory arthritis has been described rarely in the rat except that caused by Mycoplasma $[1,12]$, in spite of widespread use of the species in experimentally induced arthritis $[1,12]$. We experienced an outbreak of arthritis in a nude rat colony of small size. The nude rat carrying rnu gene in homozygosity (rnu/rnu) was reported firstly by Festing et al. [3] in 1978 as an athymic mutant which is analogous to the nude mouse. Although nude mice are known to be very susceptible to various murine pathogens $[5,7,10,11]$ and suffer frequently from the infections showing so-called wasting syndrome $[7,11]$, reports on naturally occurring diseases in the nude rats seem to be limited $[4,6,9]$.

The nude rat colony was established in 1980 by introducing an outbred Rowett hooded male rnu/rnu and female heterozygous $\mathrm{rnu} /+$ rats from the Central Institute of Experimental Animals, Kawasaki. Offspring therefrom consisted of 19 males and 7 females of $\mathrm{rnu} / \mathrm{rnu}$ and 10 males and 18 females of $\mathrm{rnu} /+$ those were born during a period from May 1980 to April 1981 were subjected for the present investigation. Two to 8 animals grouped according to the sex and age were kept in a polycarbonate cage $(\mathrm{W} 42.7 \times \mathrm{D} 26.7 \times \mathrm{H} 20.0 \mathrm{~cm}$, Tokiwa Co., Tokyo) with white flake (Charles River Japan, Inc., Atsugi) as a bedding which changed weekly, and were given pellet F2 (Funabashi Farm Co., Chiba) and acidified tap water ad libitum. These cages were placed in a laminar air flow rack. The animal room was operated without strict microbiological control procedure and conventional mice of several strains were kept in other racks in the same room. Serological examination of these mice showed positive reactions to Sendai virus and mouse hepatitis virus. Pseudomonas aeruginosa was readily isolated from the bottle water given to the animals. Therefore, all the $\mathrm{rnu} /+$ rats to be introduced were immunized with formalininactivated Sendai virus. Seromonitoring performed after their introduction revealed that these 
two virus infections disappeared from this colony.

Swelling of a hind heel joint was observed in October 1981 in two male rnu/ rnu. Since then all the rats in the colony had been subjected for weekly inspection on general condition and abnormality of joints in their extremities for 24 months. Joint swelling appeared in other rats thereafter. Some of the rats were sacrificed at various times after the onset of the joint inflammation. Some of them were subjected for detecting microbial agents from the lesions as described below. Histopathological examination was made on main organs and the affected regions. Dissected articular portions were decalcified with Planke and Rychlo solution for 1-3 days after fixation with Lilly's buffered formalin solution. Parraffin sections were made and stained with hematoxylin and eosin, Warthin Starry, and Taylor's bacterial staining methods. Additional 5 male $\mathrm{rnu} / \mathrm{rnu}$ rats at 8 weeks of age were purchased from Japan CLEA Co. (Tokyo) and 4 of them were cage-mated for 7 days with a diseased rat in August 1982. These 4 and one remaining young rats were then kept in a separate cage and observed for 12 months.

The total incidence of arthritis during the period from June 1980 to March 1983 was 19 of 55 rats (Table 1 ). The incidence in the male rnu/rnu showing 15 of 19 , was much higher than that in the female $\mathrm{rnu} /$ rnu showing 1 of 8 and the male rnu/+ showing 3 of 10 . None of 18 female rnu/+ rats showed abnormality in their joints. The date and age at the onset of arthritis in individual rats are shown in Fig. 1. A

Table 1 Incidence of arthritis

\begin{tabular}{|c|c|c|c|}
\hline & Male & Female & Total \\
\hline $\mathrm{rnu} / \mathrm{rnu}$ & $15 / 19(78.9)^{*}$ & $1 / 8 \quad(12.5)$ & $16 / 27(59.3)$ \\
\hline $\mathrm{rnu} /+$ & $3 / 10(30.0)$ & $0 / 18(0.0)$ & $3 / 28(10.7)$ \\
\hline Total & $18 / 29(62.1)$ & $1 / 26(3.8)$ & $19 / 55(34.5)$ \\
\hline
\end{tabular}

* : No. positive / No. observed (\%)

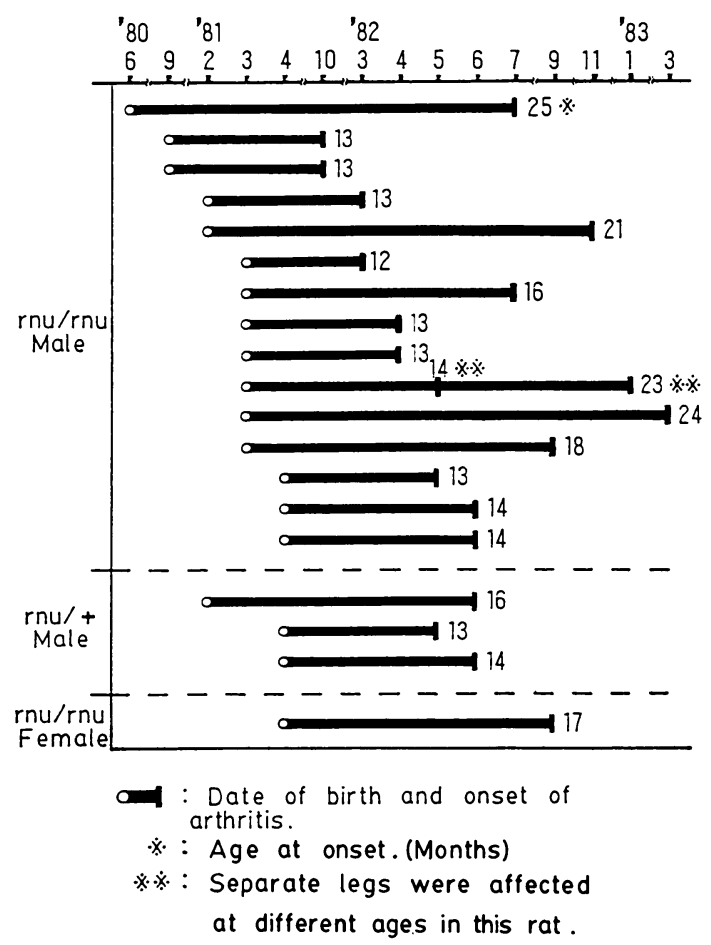

Fig. 1. Date and age at onset of arthritis

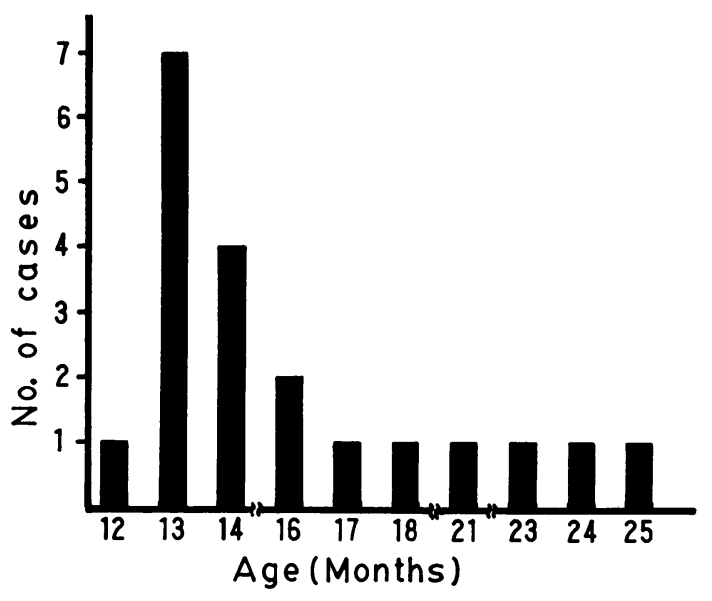

Fig. 2. Age at onset of arthritis

few cases were affected every months from March to July 1982 and then 1 incidence in 2 or 3 months period was seen thereafter. Diseased rats were distributed in almost every cages which contained male rats. There was no tendency of spreading the disease from cage to cage. 


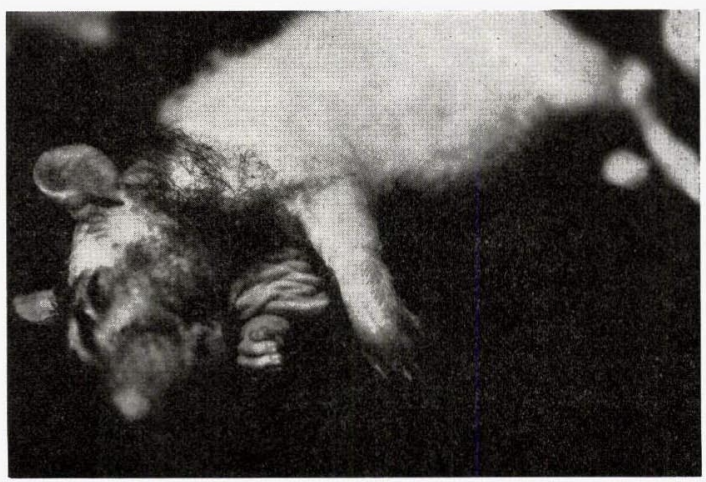

Fig. 3. Acute inflammation of carpal jojnt

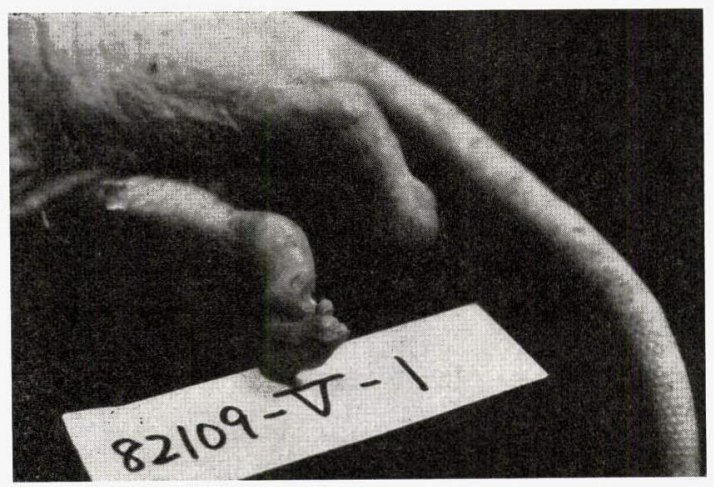

Fig. 4. Deformation of ankylosing tarsal joints

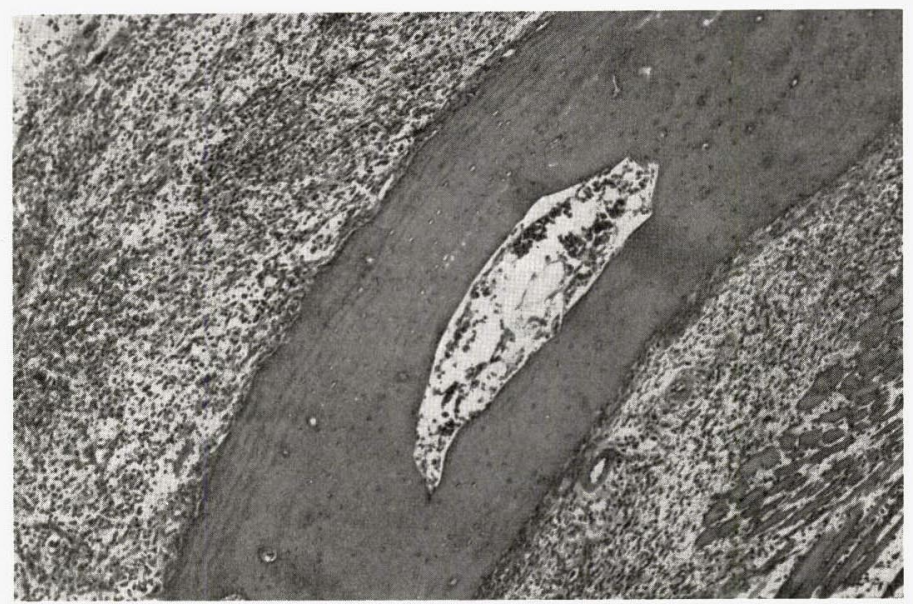

Fig. 5. Extensive edematous area with marked inflammatory cell infiltration. Carpal joint 2 days after onset of arthritis (H. E.)

Age of the rat at the onset of arthritis ranged from 12 to 25 months with a peak incidence at 13 months of age (Fig. 2).

Grossly, tarsal-and/or pedal-joint swelling with marked redness and local elevated temperature appeared suddenly. The acute swelling occurred unilaterally but occasionally the opposit joint was involved within a few weeks. In several cases, similar acute swelling was seen in the carpal- and/or digital-joints (Fig. 3). One rat experienced second joint swelling at a fore foot 8 months after the first attack of a hind foot (Fig. 1 \% $)$. The acute swelling disappeared within one week in the majority of cases, leaving only a slightly firm, mild swelling for months. However, in 5 of 15 arthritic male nude rats, considerable swelling persisted for several months and subsequent ankylosing osteoarthritits developed. Two of these rats left to alive for months, developed osteoarthritis at both knee joints, and could not stand by their feet (Fig. 4).

Histological examination 2-3 days after the onset revealed acute exsudative inflammation in soft tissues surrounding the articulation. The lesions were associated with cellular infiltrations mostly composed of neutrophils and some mononuclear cells 


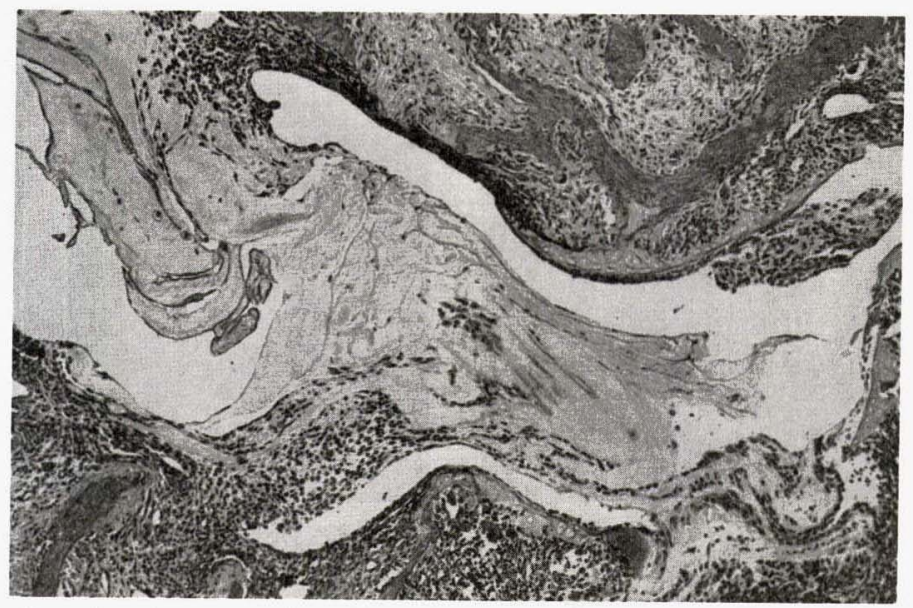

Fig. 6. Degeneration of cartilage and pannus formation in ankylosing tarsal joint (H. E.)

(Fig. 5). No inflammatory change was seen in the tendon itself and the articular cavity although the tendon sheath and synovial membrane were involved showing slight hyperplasia of synovial cells. A case showing considerably swollen tibiotrasal joint and examined about 2 weeks after the onset formed subsynovial granulation tissue with pleomorphic synovial cells. Edematous changes with neutrophils and mononuclear cells, sometimes with macrophages, were seen in the periarticular soft tissues. In the periosteum of the epiphysis, many active osteoclasts were observed. In 5 cases revealing ankylosing lesion, cellular infiltration, hyperplasia of synovial cells and proliferation of fibroblasts were conspicuous in subsynovial tissues and articular cavities. Erosion of the articular cartilage and pannus formation were seen in the femorotibial, patellar, tibiotarsal, brachiocarpal, pedal and digital articulations (Fig. 6), in the epiphysis of which marked exostosis occurred. In some of these cases, the heart, spleen, liver, lungs, and kidneys were examined histologically. Although lesions associated with aging, such as endocardial proliferative lesions, cholangiofibrosis, or pulmonary foamy cells were noted [2], any changes suggesting the etiology of the arthritis were not recognized.

Sera obtained from all rnu/+ rats in June 1982 revealed no positive reaction to Mycoplasma spp. (M. pulmonis and $M$. arthritidis) at a serum dilution of $1: 10$ by the complement fixation test. Anti-Sendai virus antibodies were detected only in the immunized animals (at $1: 10$ by ELISA) [8]. Two cases were positive to Corynebacterium kutscheri antigens (1:10 by agglutination test), however, the pathogen seemed not to be prevailed in this rat colony since repeated trials could not isolate the bacterium from animals of this colony. Attempts to detect agent from the affected articular regions failed to find any meaningful organisms either by aerobic culture on blood agar ( $5 \%$ horse blood in Trypticase Soy Agar, Eiken Co.) at $37^{\circ} \mathrm{C}$, or by inoculation onto a medium for Mycoplasms spp. (Difco Co.). The smear preparations stained with Giemsa or Gram techniques could not show microorganisms with diagnostic certainty.

The clinical and histologic features of the present cases resembled to those of mycoplasmal arthritis in the rat. However, we could not find any evidence of mycoplasmal infection neither by isolation trials nor by checking seroconversion of the immunocompetent $\mathrm{rnu} /+$ rats in this 
colony. No other bacterial or protozoan organisms were detected. This condition seemed to be accumulated within about 6 months period and thus a contagious nature was suspected at first. However, the transmission trial could not confirm the contagious nature. Concerning the cause of this arthritis, the age distribution may be important. All the cases developed arthritis at 12 months of age or older. In addition, an 8 week-old nude rat newly introduced to this room in August 1982 as a control kept in a separate cage produced the joint swelling when the rat reached 15 months of age, far after the prevalence in the primary group. An interesting fact in this outbreak of arthritis is that the majority of cases were seen in athymic male nudes. Although the causal factor of this disease remains to be solved, preference in the male sex and thymus-less mutant might be related closely to the production of this disorder.

\section{Acknowledgement}

The authors are grateful to Drs. K. Koshimizu and S. Kawamura, University of Tokyo, and S. Yokoiyama, Toyo Jozo Co. Ltd., for supplying Mycoplasmal or Corynebacterial strains. We also thank Miss T. Mochizuki for typing this manuscript.

\section{References}

[1] Alspaugh, M. A., and Van Hoosier, G. L. Jr. (1973) Lab. Anim. Sci., 23, 724-742.

[2] Anver, M. R., and Cohen, B. J. (1979) In the Laboratory Rat, Vol. I, pp. 378-399, Baker H. T., Lindsay, J. R., and Weisbroth, S. H. (edit.), Academic Press, New York.

[3] Festing, M. F. W., May, D., Connors, T. A., Lovell, D., and Sparrow, S. (1978) Nature, 274, 365-366.

[4] Festing, M. F. W. (1981) In Immunologic Defects in Laboratory Animals, Vol. I, pp. 267-283, Gershwin, M. E., and Merchant, B. (edit.), Plenum Press, New York.

[5] Fujiwara, K., Tamura, T., Taguchi, F., Hirano, N., and Ueda, K. (1977) In Proceedings of the Second International Workshop on Nude Mice, pp. 53-60, Nomura, T., Ohsawa, N., Tamaoki, N., and Fujiwara, K. (edit.), University of Tokyo Press, Tokyo.

[6] Halter, S. A., Wetherall, N., and Holscher, M. (1983) Lab. Anim. Sci., 33, 287-289.

[7] Hirano, N., Tamura, T., Taguchi, F., Ueda, K., and Fujiwara, K. (1975) Jpn. J. Exp. Med., 45, 429-432.

[8] Iwai, H., Yamaguchi, R., Otsuka, Y., Ueda, K., and Saito, M. (1984) Microbiol. Immunol., 28, 481491.

[9] Moore, G. J. (1979) Lab. Anim., 13, 35-36.

[10] Ueda, K., Goto, Y., Yamazaki, S., and Fujiwara, K. (1977) Jpn. J. Exp. Med., 47, 475-482.

[11] Ueda, K., Tamura, T., Machii, K., and Fujiwara, K. (1977) In Proceedings of the Second International Workshop on Nude Mice, pp. 61-69, Nomura, T., Ohsawa, N., Tamaoki, N., and Fujiwara, K. (edit.), Unversity of Tokyo Press, Tokyo.

[12] Woodard, J. C. (1978) In Pathology of Laboratory Animals, pp. 664-820, Benirschke, K., Garner, F. M., and Johnes, T. C. (edit.), Springer-Verlag, New York.

\title{
Hooded 系ヌードラットの関節炎
}

\author{
町井研士・山崎省二・岩井汯・佐野玲子・上田雄幹
}

国立公笔衛生院衛生獣医学部

Rowett hooded 系ヌードラットコロニーで, 関節炎 の自然発症に遭遇した。発症は 12 月龄以上のヌード $\mathrm{rnu} / \mathrm{rnu}$ 雄 $(15 / 19)$, ヘテロ $\mathrm{rnu} /+$ 雄 (3/10) 及び $\mathrm{rnu} / \mathrm{rnu}$ の雌 $(1 / 8)$ にみられた。病变は四肢端関節部 の発赤, 腫脹として発見され, 組織学的には, 関節周囲 軟組織の滲出性炎であって, 多くは軽度に局所の硬結を
残すのみで治瘑したが，一部の $\mathrm{rnu} / \mathrm{rnu}$ では関節強直 にまで進展し，パンヌス形成，外骨症がみられた。病変 局所の培養, $\mathrm{rnu} /+$ 個体の血清抗体検索では, 病因と 思われる微生物は検出されなかった。本関節炎の病因に ついては, 不明であるが, 年㱓, 性及び胸腺久損が深く 関与していると思われる。 